\title{
RESEARCH ON HOUSING AND URBAN IMPROVEMENT PROCESS FOR LOW INCOME POPULATION
}

\author{
The case of self-help housing and urban self-management in Lima, Peru \\ リマ都市圈における低所得者層の居住環境改善プロセスの実態と課題 \\ セルフ・ヘルプ・ハウジングとアーバン・セルフ・マネージメントに着目して
}

\author{
Junko TAMURA*, Shinya MIYAZAKI ** and Kentaro HONMA*** \\ 田村順子，宮崎 慎也，本間 健太郎
}

\begin{abstract}
Self-help housing that has been introduced in many schemes as a solution to assist self-builders in construction of their own dwellings and urban self-management, which is acknowledged as successful participatory development established in Peru, are both recognized internationally despite of having aspects of success and failure as aided schemes for the low-income population implemented in other developing countries. Therefore, the aim of this paper is to evaluate self-help housing and urban self-management by first defining different types of housing and urban improvement process with flow-charts showing urban process and housing solution, then summarize main findings through physical condition, impacts and side effect of three project areas in Lima.
\end{abstract}

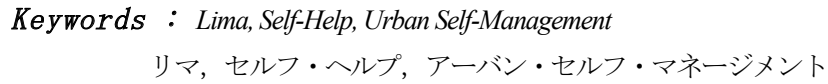

\section{Introduction}

The rapid growth of population caused by industrialization and the lack of employment opportunities in rural areas often created illegally or informally developed settlements in the city. In these areas, low-income population who are unable to afford the smallest or cheapest legal house, lived in poor housing conditions with little or no piped water, sanitation or services ${ }^{1)}$. Therefore, with the growing awareness of providing adequate shelters recognized by the United Nations Conference on Human Settlements (Habitat) held in 1976, various strategies were employed to curb the housing crisis in developing countries.

In Peru, the internal migration started during 1920s from sierra - the mountainous areas, to costa - the urbanized areas along the coasts, creating informal settlements in the peripheral of the city, usually on steep sloped lands at the foothills of the Andes. These unauthorized areas are given a local name Barriadas $^{* 1)}$, which are expanding still today. Barriadas expanded rapidly in Lima when the population ratio of sierra and costa inversed during 1961 to 1972 while urbanized area of costa showed gradual increase and exceeded sierra ${ }^{2), 3), * 2)}$. As solution to this housing crisis due to relentless migrations, provisions for low-income housing became major tasks for government policies of 1970s in Peru, which focused mainly on housing supply, urban reconstruction and rehabilitation works ${ }^{4}$, and this paper focuses on self-help housing that was adopted in many housing projects worldwide during this period, and urban self-management that was established as a way of improving urban environment through area-based community organization, both of which were originated in Peru.

\subsection{Self-help housing}

Self-help housing was advocated by William Mangin and John Turner, who surveyed Peru during late 1960s. From their observations, most squatters had jobs, therefore were socially stable and that illegal occupancy of land was a way to avoid from bearing the expenses of high rents and allowed to build their homes at their own pace ${ }^{5}$. Moreover, Turner saw economies of self-help founded upon "the capacity and freedom of individuals and small groups to make their own decision," and all that had to be done was to distribute small amounts of cash in the appropriate stages to the self-builders ${ }^{6}$. This positive force in

\footnotetext{
* Department of Architecture, National University of Singapore, Dr. Eng.

** Department of Architecture, Fukuoka University, Dr. Eng.

*** Institute of Industrial Science, The University of Tokyo, Dr. Eng.
} 
housing provision later fostered and facilitated the Aided Self-Help, which nowadays is known as the Sites and Services scheme.

Sites and Services as a scheme for aided self-help, is a slum upgrading approach to facilitate self-help housing for the low-income population by providing plots and infrastructure. It involves opening up of new land and subdivision of plots to provide each families with security of land tenure, which are serviced with utilities. Types of services ${ }^{* 3)}$ provided and initial stages of dwellings vary according to the policy of the scheme implemented under different context ${ }^{7}$. The shelter component also ranges from no shelter to with core unit of which the type or the size of houses and the consolidation ${ }^{* 4)}$ speed using method of self-help depended on individual's income and expansion of family size. Although employed in 50 different countries ${ }^{8}$, this scheme has known to have failed for reasons most commonly due to lack of affordability, location of implemented site being not close to the inner-urban area (work place), subletting and selling of the houses. Moreover, in most cases, contractors constructed the core houses rather than beneficiaries applying the method of self-help. This was because the scheme used modern permanent materials where constructions required services of building professionals $^{8)}$ and high maintenance costs made the house unaffordable $^{\left.*_{5}\right)}$ for the low-income population that lead them to sublet and to move out. As a result of absence of owners, it usually caused problems to the neighbourhood environment in that there were no caring of the garbage collection, street cleanings, which were poorly organized and thus, left the area in filthy condition ${ }^{9}$.

\subsection{Urban self-management}

Focusing on the nature of autonomy seen in self-help housing, Peru established a particular way of improving urban conditions, which has been acknowledged nationally and internationally as the urban self-management. It is a bottom-up approach to curb the urban crisis and essentially, the participant entities were area-based and specific-purposed community organizations. Therefore, as opposed to sites and services approach, this method facilitates the development of a city by and for its own resident families, specifically with the provision of servicing infrastructure.

With the pioneering project of Villa El Salvador's case of Lima, urban self-management succeeded with the citizen participation playing importance on social organization and providing opportunities for dialogue with local organizations in the development process ${ }^{10)}$. The participant included hundreds of area-based and specific-purpose community organizations, several Peruvian government bodies, the metropolitan municipality of Lima, district municipality, several international and local nongovernmental organizations, international aid organizations, and the Catholic Church. As a result of this direct dialogue, Villa El Salvador Integrated Development Plan was approved ${ }^{11)}$.

The development of Peruvian informal settlements in general follows unwritten but certain rules, which can also be seen in urban self-management with the process of urban improvement. After the approval of a plan allowing securing of land, the first thing to be built is a school for small children who cannot commute afar to study. Next comes the development of infrastructure - most commonly electricity, then water and sanitation. Finally, paving of the roads ${ }^{11}$.

\section{Research Objectives and the Evaluation Criteria}

Self-help housing has been adopted in many housing projects worldwide as aided self-help and urban self-management that similar method in more customary way can also be seen in some other countries as a solution to enable urban improvement ${ }^{12)}$. This paper aims to give basic understanding of self-help, which sometimes failed to facilitate in aided housing schemes $\left.{ }^{13)}{ }^{14}\right)$ and give a wider scope of effects urban self-management may imply in the process of urban improvement.

This paper monitored nine houses in three sites of Lima specifically focusing on areas developed during 1970s. Surveys were made by interviewing the owners and drawing house plans with the history of expansion, to evaluate self-help housing and urban self-management giving thoughts in ways of housing and urban improvement process for the low-income population. The evaluation criteria will be done by first, defining different types of housing and urban improvement process using two simple flow charts of housing and urban process, and summarize the main findings with respect to physical condition, impacts and side effect of each project. Finally, the evaluation aims to draw conclusions on issues that could occur in the process of housing consolidation, which may help to give better understand in future studies to find some functions of failure and success seen in aided schemes such as sites and services implemented in other countries.

\section{Housing and Urban Process}

Housing and urban process can be defined into various types $\left.\left.\left.{ }^{5}, 6\right), 8\right), 15\right), 16$ ) according to two flow-charts shown in fig. 1.

\subsection{Urban Process}

Urban Process is basic living environment that can be verified into five types distinguished by four elements: Site-security of land tenure, Service-basic infrastructure including water and sewerage connections, pit latrines (wet core), access roads and basic street lights, Core House-shell of a house provided on the site, Aided - funding by the government or international organization. Using the flow-chart, various settlements can be identified into Type I to V where Type I represents unplanned area and Type II to V represents planned areas. 
Type I: Informal settlements-barriadas.

Type II: Settlements with no infrastructure but allottees are given security of land tenure.

Type III: Developed area in similar condition to Type II but with serviced infrastructure.

Type IV: Aided version of Type III, with or without a core house depending on the policy - sites and services.

Type V: Developed area provided with a house and a lot, non aided - complete home.

\subsection{Housing Solution}

Housing solution is the consolidation process of a house that can be differentiated into three methods, Method A to C. The first process of housing consolidation is the Auto-Construction ${ }^{4}$, which is the incremental step of a housing unit that is in an incomplete state with only wet core and/or firewall provided at the initial stage, such as in sites and services. In this system, housing units, either small or big, provided in conditions ready to move in and incremental step starts from the provision of expansion, will not be defined as auto-construction.

Method A: Complete dwelling-PREVI ${ }^{*}$ )

Method B: Cooperation of all participating families in teamwork only in the construction and improvement of their own dwelling

Method C: Use of participating family members' skills, labour, organisational talents and managerial skills in the construction and improvement of their own dwelling8).

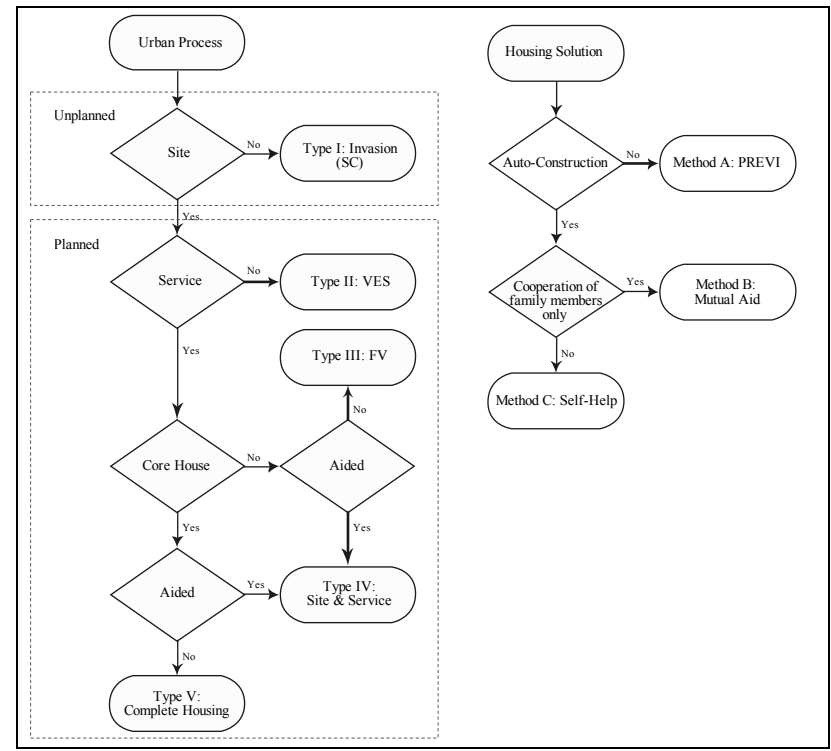

Fig.1 Flow-charts

4. Background on housing and urban improvement process in surveyed areas

Three sites were selected to monitor housing and urban improvement process in Lima by two criteria: 1) all three sites have different urban processes-Type I, II and III*7), but 2) all three sites have common housing solution-Method C only.
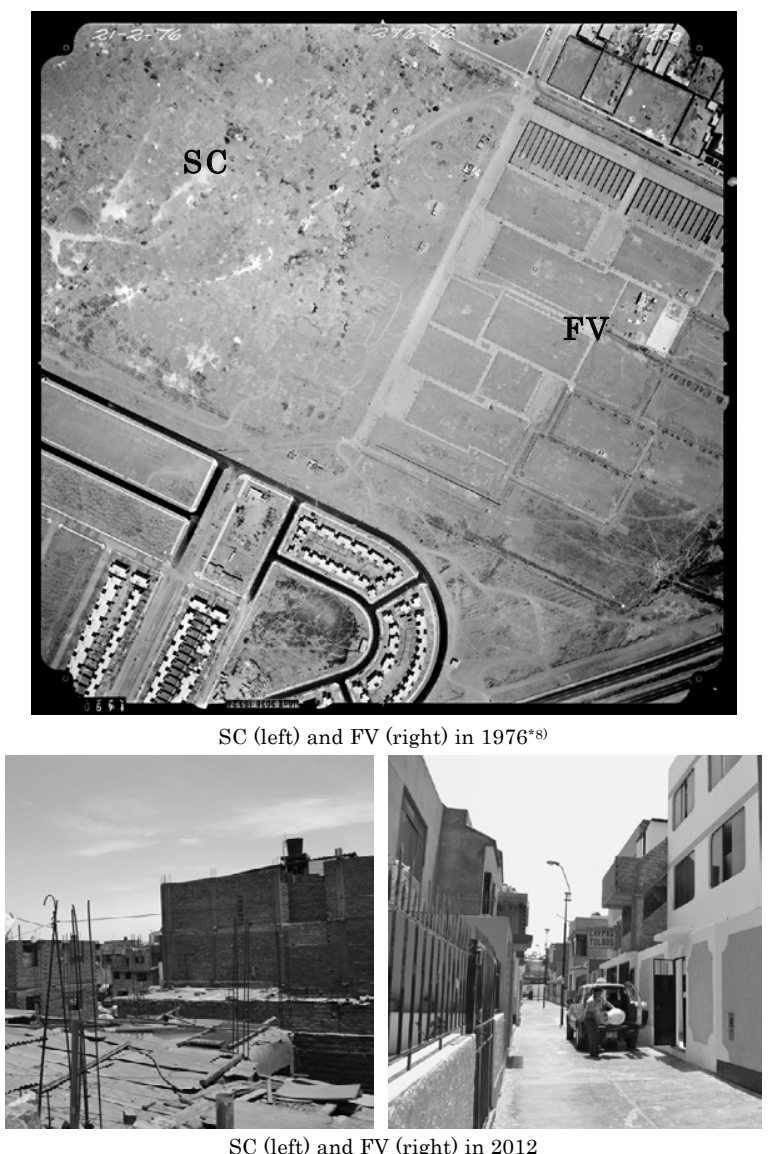

Fig.2 Fundo Vasquez and Sicuani

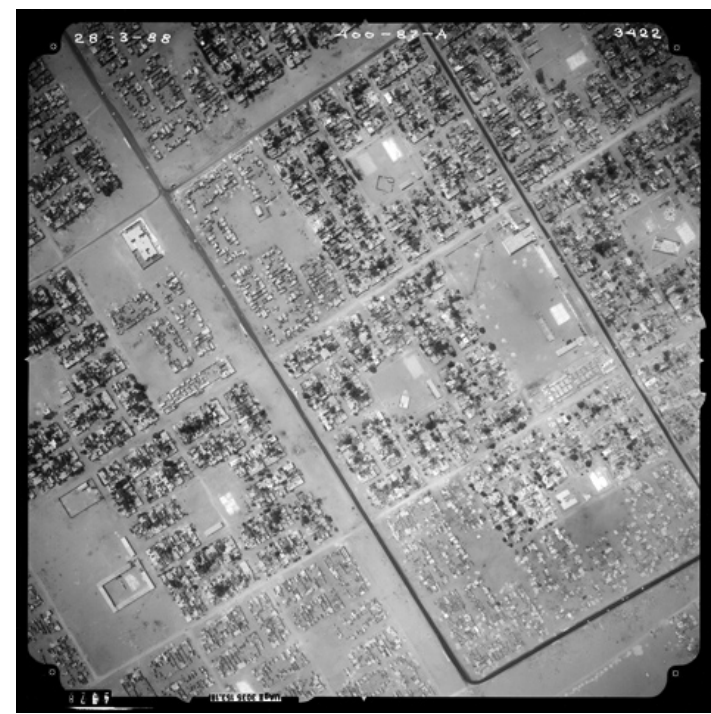

VES in $1988^{* 8}$

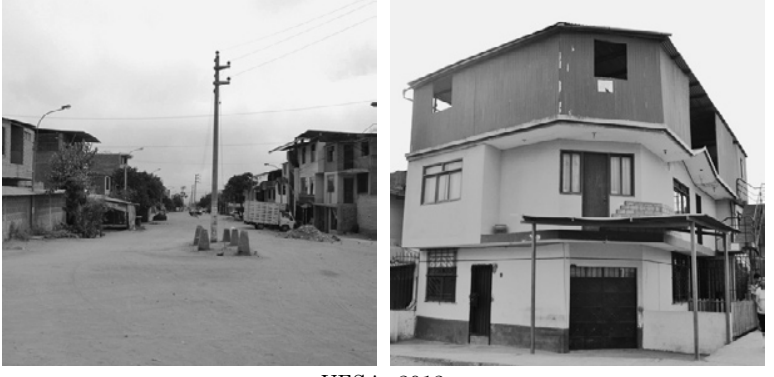

VES in 2012

Fig.3 Villa El Salvador 


\subsection{Fundo Vasquez-Type III, Method C}

Fundo Vasquez (FV) belonging to Type III in urban process is located in Ate district, the eastern part of the province. It was agricultural land until 1969, when agrarian reform expropriated all estates above certain size. After the reform, Peruvian Navy acquired the land for development, which did not succeed and sold the area to Ministry of Housing and Construction (MVC: Ministerio de Vivienda y Construcción). The initial project planned by MVC was to develop industrial / housing area (Case Taller), which also failed to succeed and as a result, the land was subdivided into 400 plots in 1977 , maintaining 120 to $200 \mathrm{~m}^{2}$ per lot providing residential area partly for employees of water supply and sanitation company (SEDAPAL), Ministry of Tourism and to the residents of Manzanilla in La Victoria district. La Victoria is a low-income residential area developed in 1940s for industrial and shop workers but due to problems caused by over population, some of the residents were given priority to relocate their homes in $\mathrm{FV}^{*}{ }^{9}$ ).

\subsection{Sicuani-Type I, Method C}

Sicuani (SC) belonging to Type I in urban process is located also in Ate district, at the western side of FV. It was the site selected for the implementation of urban sites and services development project appraised in 1976 by the World Bank ${ }^{* 10}$. However, due to changes in the government, this project was never implemented despite of having completed the selection of approved applicants. Therefore, SC planned to have belonged to Type IV in urban process but because of the unfortunate turnover, it ended up being Type I at the stage of implementation.

However, the approved applicants started invading empty project site in SC and created informal settlement in 1981. By 1985, the area was approved by the government as Asentamiento Humano ${ }^{* 1)}$ and secured their land. SC was then demarcated into 900 plots of size $120 \mathrm{~m}^{2}$ per lot and later on, the allottees, through social process of neighbourhood initiatives self-managed to install utilities, which as a result SC became part of the city ${ }^{* 11)}$ (fig. 2).

As in the typical process of urban improvement, SC consolidated schools - kindergarten, junior and senior school, infrastructureelectrification, water supply and sanitation, roads, and other services such as community parks and churches. Door-to-door collection was used for raising money to buy construction materials and usually $5 \%$ interest on top to hire labour. Ate district municipality supported $50 \%$ for paving roads and international funding from Hungary helped in paving sidewalks ${ }^{* 11}$.

\subsection{Villa El Salvador-Type II, Method C}

Villa El Salvador (VES) belonging to Type II in urban process is located on the outskirts of Lima, which was founded on May 11, 1971 by urban development authorities in Velasco Alvarado's military government (fig. 3). It received 30,000 households in total with approximately 7,000 relocated families from Monterrico who were given priority in the selection criteria of applicants ${ }^{* 12}$. Monterrico is a high-income residential area where barriadas was created in the private lands of this district causing conflicts with the original residents. Therefore, barriadas residents were in target of eviction and VES, where it was vast empty sand flats was selected as the project site of relocation. Typical locational model of informal settlements in Peru can be found in the peripheral areas of the city, which expand outwards invading hills and consequently, slum upgrading projects are often based on on-site upgrading, thus making the case of Monterrico relocation plan relatively rare ${ }^{\left.*_{13}\right)}$.

As for selection of other applicants, public announcements through newspapers and other media were promoted to offer rest of the lots to any families who needed accommodation. To be eligible for a plot, an applicant had to be married and have not yet purchased a house but monthly income was not part of the selection criteria*14). After registration stating the two requirements, applicants were given a plot in VES for free.

VES turned into a huge urban zone after 1971 having provided $140 \mathrm{~m}^{2}$ to $180 \mathrm{~m}^{2}$ per lot with land tenure but no utilities were serviced at the time. Therefore, water, sewage and electricity were supplied through efforts of area-based community organizations and in 1973, Urban Community of Villa El Salvador (CUAVES) was established to self-manage the area10), 11). This paper surveyed Sector 3 in VES and in this area, construction of schools, infrastructure and streets lights were implemented during 1971 to $1975^{10),}{ }^{11)}$, electricity was serviced in 1976 and water was piped in 1977. The community paid 40 US $\$$ per month per house for two years to raise funds for construction of infrastructure ${ }^{* 14)}$.

\section{Evaluation}

Survey plots for this paper were chosen from Ate-Fundo Vasquez and Sicuani, and Villa El Salvador-Sector 3. For security reasons, the houses were selected based on social networks of these areas - friend introducing another friend and so on, and as a result, nine houses were surveyed, which were also supported by dialogue with relevant national government agencies, the MVC and local community leaders of each site. The survey took place through 29 February to 6 March, 2012.

Table 1 shows basic information of each surveyed houses. It includes the location of the house (Site), the ownership - whether the current owner of the house is the original owner or bought through someone else (Ow), the age of the interviewee (Age), number of households (Hh), number of household members $(\mathrm{Hs})$, number of tenants if applicable $(\mathrm{Te})$, the year current owner started to occupy the land (Occp), the year when the first floor of the house was completed $(1 \mathrm{~F})$, number of storeys (fl), self-help - whether self-help was adopted in the 
Table 1 Surveyed houses

\begin{tabular}{|c|c|c|c|c|c|c|c|c|c|c|c|c|c|c|}
\hline & Site & Ow & Age & $\mathrm{Hh}$ & $\mathrm{Hs}$ & $\mathrm{Te}$ & Occp ${ }^{* 15)}$ & $1 \mathrm{~F}$ & $\mathrm{Fl}$ & $\mathrm{SH}$ & $\mathrm{SM}$ & $\mathrm{Hp}$ & $\mathrm{Np}$ & Rs \\
\hline 1 & FV & $x$ & 48 & 3 & 16 & - & 1977 & 1980 & 3 & $\checkmark$ & $x$ & $\checkmark$ & $x$ & $\checkmark$ \\
\hline 2 & FV & $\checkmark$ & 62 & 1 & 4 & - & 1985 & 1994 & 3 & $x$ & $x$ & $\checkmark$ & $x$ & $\checkmark$ \\
\hline 3 & FV & $x$ & 76 & 1 & 2 & - & 1997 & $\mathrm{NA}^{* 16)}$ & 1 & $\left.\mathrm{NA}^{*} 16\right)$ & $x$ & $\checkmark$ & $x$ & $\checkmark$ \\
\hline 4 & FV & $\checkmark$ & 65 & 2 & 15 & - & 1990 & 1990 & 2 & $\checkmark$ & $x$ & $\checkmark$ & $x$ & $\checkmark$ \\
\hline 5 & FV & $\checkmark$ & 70 & 3 & 11 & 5 & 1977 & 1980 & 4 & $\checkmark$ & $x$ & $\checkmark$ & $x$ & $x$ \\
\hline 6 & $\mathrm{FV}$ & $\checkmark$ & 45 & 2 & 9 & 6 & 1987 & 1995 & 3 & $\checkmark$ & $x$ & $\checkmark$ & $x$ & $x$ \\
\hline 7 & $\mathrm{SC}$ & $\checkmark$ & 79 & 1 & 4 & 6 & 1981 & 1986 & 3 & $\checkmark$ & $\checkmark$ & $\checkmark$ & $\checkmark$ & $x$ \\
\hline 8 & VES & $\checkmark$ & 69 & 3 & 10 & - & 1971 & 1980 & 2 & $\checkmark$ & $\checkmark$ & $\checkmark$ & $\checkmark$ & $x$ \\
\hline 9 & VES & $\checkmark$ & 71 & 1 & 5 & 6 & 1972 & 1990 & 3 & $\checkmark$ & $\checkmark$ & $\checkmark$ & $\checkmark$ & $x$ \\
\hline
\end{tabular}

consolidation and expansion of the house ( $\mathrm{SH}$ ), self-management - whether the site of the house required urban self-management in the improvement of the area or not (SM), house preferencewhether people are satisfied with their house or not (Hp), neighbourhood preference - whether people like the neighbourhood or not $(\mathrm{Np})$, resettlement plan-whether people have plans to resettle in other place or not (Rs).

\subsection{Evaluation Findings on Self-Help Housing}

When Method C is used for housing solution in Peru, the consolidation process begins by first, fencing the border of the lot to define the site boundary. The construction material for the shelter component improves by building up exterior walls using thatched materials called choza or totora, then wooden plates replace the initial ones and finally completes when bricks are laid. The next step is the construction of demarcation walls to separate interior space into private rooms and the consolidation completes when concrete roof is placed on top ${ }^{17)}$ of the building. Through visual observation of houses in surveyed areas and interviews ${ }^{* 12}$, ${ }^{* 14}$, the expansion process can be described in the order of either one of the followings:

1) wall $\rightarrow$ kitchen ${ }^{* 17)} \rightarrow$ toilet and shower $\rightarrow$ bedroom $\rightarrow$ roof

2) wall $\rightarrow$ toilet and shower $\rightarrow$ bedroom $\rightarrow$ kitchen $^{* 17)} \rightarrow$ roof.

Through interviews to the local people (Table 1), it was found that consolidation period (from the year of occupation until core unit of the first floor is completed) could take up few to approximately ten years, and then start expanding their house depending on family income (fig. 4). Eventually, as children grow up during this period and start earning, the house transforms into two-family house or even three until the second stage of expansion begin upwards to build second, third floors and even more. House 5 and 6 are distinctive examples representing such case. Besides, the owner makes provisions for subletting the house partly to tenants ${ }^{* 18}$ ) (in Lima, the owners usually live in the same house with their tenants) in which the rents become important income for those especially who have already retired such as house 5, 7 and 9 (fig. $5: \mathrm{a}-1 \mathrm{~F}$ and $2 \mathrm{~F}, \mathrm{~b}-3 \mathrm{~F}, \mathrm{c}-3 \mathrm{~F}$ ).

As consequence of self-help in common, the level of satisfaction with people's homes is high. The method of self-help is indigenous as observed by Mangin and Turner decades ago, and has been adopted through generation after generation in Peru. For this reason, those who have acquired land will make their own plans for expanding their homes, which were to be seen from results of the surveyed houses. Besides the efforts of the individuals and family members, the presence of Maestro de Obra*19), who are in every community-even in barriadas, were found to have played an important role in the consolidation process and it can be said that without maestro, self-help as a method of housing solution could not have been easy to succeed $\left.{ }^{*} 13\right)$, * $\left.{ }^{*} 4\right)$.

\subsection{Evaluation Findings on Urban Self-Management}

In places where urban self-management was employed (House 7, 8 and 9), people had in common that "the neighbourhood was created through community's efforts" and they may "one day go back to the rural area" which are their hometowns, usually where they grew up, but are "not considering to resettle

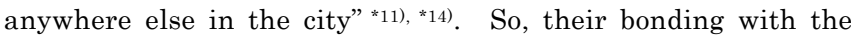
neighbourhood and the community is considerably high.

On the other hand, besides SEDAPAL residential area in FV where people have stayed since the beginning of the implementation, many of those who have resettled from La Victoria residential area of FV have gone out to live in other areas or have been subletting rooms to tenants with the absence of owner. There are various reasons for leaving, most distinguishable one is that people in La Victoria district were originally from a relatively low-income class and although they were given the priority to register for acquiring the land at the initial stage, the plots provided were simply not affordable for them and had to sublet or to sell the property. House 1 and 3 are examples of this where the original owners have left the area and passed the tenure to the current owner.

The newcomers and long resided residents often cause conflicts pressuring people to move out - it usually happens when the tenants or new owners are not fully screened by the original owner of the house. Through interviews, it was found that since few years ago, the area of houses 1 to 6 have dramatically changed due to the inflow of migrants and many residents' preference of neighbourhood today is low because they feel "lack of security" and as for houses 1 to 4, they "want to move out" as soon as they "find a better place" or "have enough money" *9). 


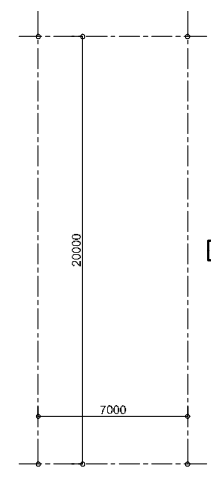

$\times 1971$

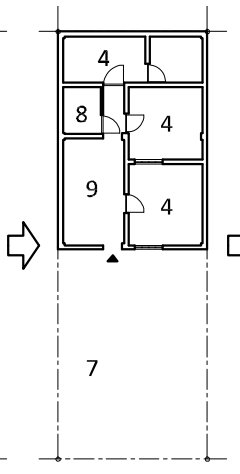

1976

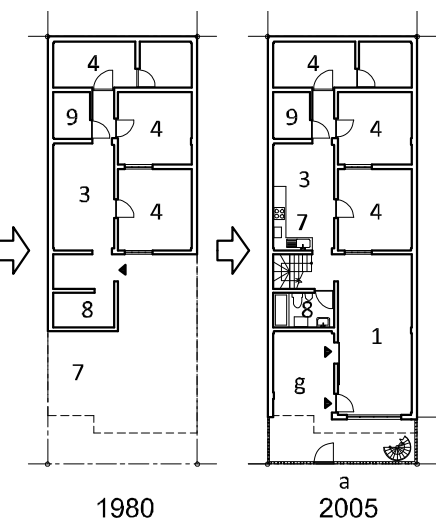

Fig.4 Consolidation and expansion process of surveyed house 8
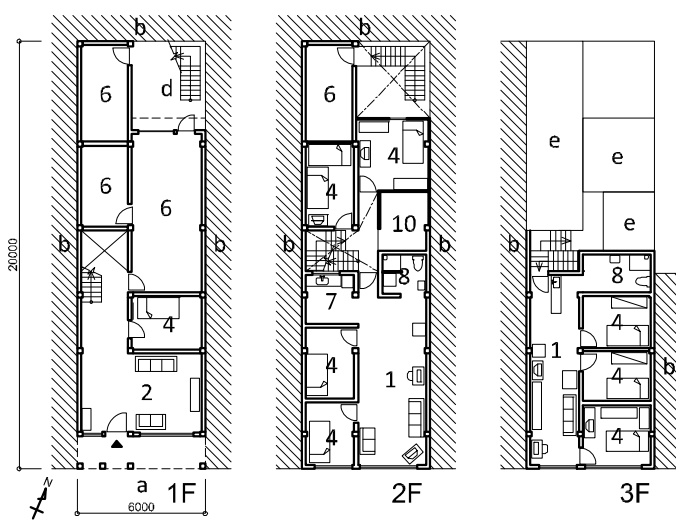

1. Living room

3. Dining room

4. Bedroom

5. Study

6. Tenant
7. Kitchen

7. Kitchen
8. Shower + Toile

9. Utility room

0. Storage

11. Workshop

Multipurpose

space

a. Access Road

b. Neighbouring

house

d. Courtyard

d. Courty

e. Roof

f. Greenery
g. Garage

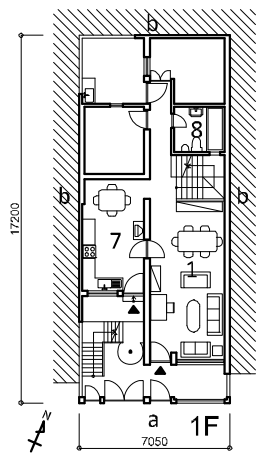

a) House 6
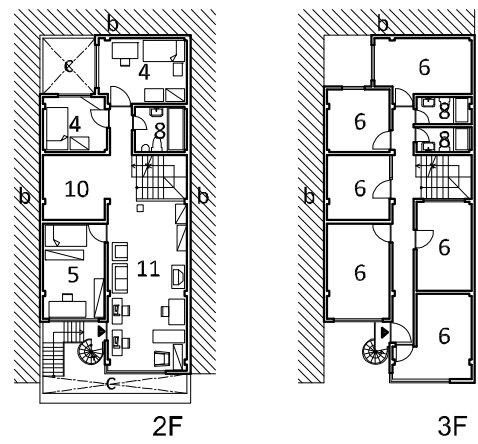

b) House 7
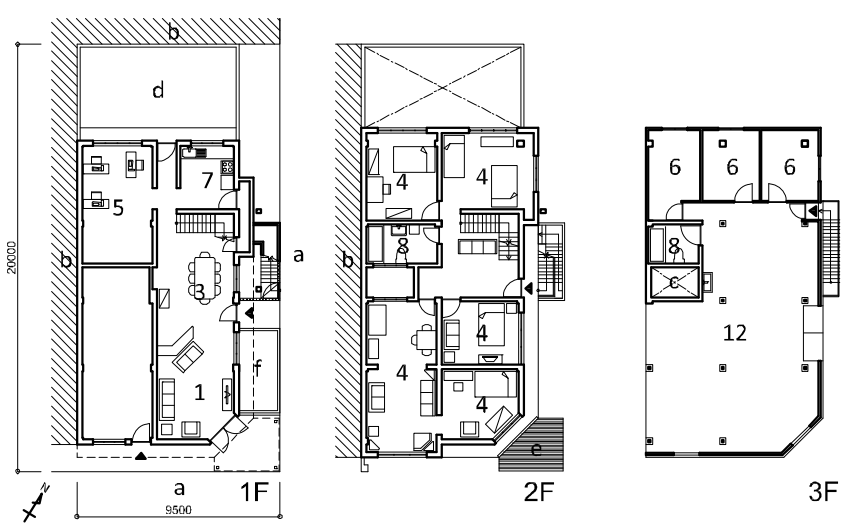

c) House 9

Fig.5 Plans of surveyed houses

\section{Conclusion}

\subsection{Summary of Survey Results}

Despite different interviewed items shown in table 1, seven out of nine houses in common adopted the method of self-help and all nine houses gave good results with high level of satisfaction in the current condition of their homes. It was also discovered that all houses were satisfied with their community and that community bonding is still at presence, however, houses 1 to 6 , showed hesitations towards newcomers and live to fear with lack of security, which as a result, houses 1 to 4 are considering of moving out. On the other hand, houses 7 to 9 were satisfied with their neighbourhood and have no plans to resettle in another place in the city. The first four and the latter three houses in correspondence can be classified as whether urban self-management has been applied in the improvement of the area or not.

\subsection{Implications}

On-site housing and urban improvements, which although estimates triple ${ }^{* 13),{ }^{*} 20}$ the cost of off-site improvements ${ }^{* 21}$ ) are most commonly employed in Peru. Focusing on financial aspects only, provision for urban self-management that requires long-term investment is a severe strain for the low-income population that either government or international funding will benefit them in establishing and/or completing their homes and the concept of aided self-help is thus effective. Nevertheless, subletting and selling of the property seen in such aided projects as in sites and services of other countries, the housing policy must be once again re-evaluated in terms of concerning sustainability of the project.

Table 2 shows the evaluation arranged according to three sites instead of by houses, which compares differences in terms of physical condition, impacts and the side effect that can be seen today ${ }^{* 22}$. This table gives us the idea that the action of self-help and self-management may contribute to positive impacts on various evaluation components. Even SC, which started by invasion, has resulted with a city of good housing standard, community bonding and neighbourhood security.

On the other hand, FV that was fully utilized, where self-management was a minor issue in this residential area ${ }^{* 23}$ does not classify high in the community bonding and neighbourhood security. Within recent few years, the community bonding in FV reached a critical point in the balance between the force of connection and disconnection, and from the interviews, the reasons were considered to have lead by the growing numbers of subletting, selling and absence of owners. As a result of this consequence and the lack of security seen in this survey, it drove incentives of people willing to resettle in other places instead of improving the area. From this, it can be implied that self-help housing and urban-management may state as being one of essential systems in the formation process of a city 
and in sustaining good quality living environment.

As Turner points out, "there's much to be learnt by architects of how people display their living," which can be seen in many developing countries ${ }^{18)}$, introducing the nature of autonomy seen in self-help housing and urban self-management as method of consolidation in housing policies remains questions to be solved $^{* 24)}$. For example, maestro de hobra who helps the community in the consolidation process of houses are unlikely to

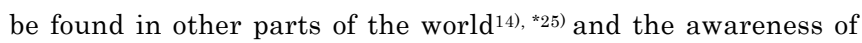
citizens in participating the organization can also vary depending on family structure and social system - such as individualism or nuclear family, of a region in our modern society. Nevertheless, this paper suggests the scope of evaluation especially with the nature of subletting and selling of the houses, which are considered undesirable, and the roles of self-help and urban self-management that may contribute in the housing and urban improvement for low-income population. Therefore, further researches require monitoring different cases of self-help and urban self-management that emerges spontaneously, thus we can understand further impacts of both the positive and negative aspects of these methods.

Table 2 Evaluation of projects

\begin{tabular}{|c|c|c|c|c|}
\hline \multirow[t]{2}{*}{ Component } & \multicolumn{3}{|c|}{ Evaluation } & \multirow[t]{2}{*}{ Comments } \\
\hline & $\mathrm{FV}$ & $\mathrm{SC}$ & VES & \\
\hline \multicolumn{5}{|c|}{ Physical Condition } \\
\hline Sites & Provided & - & Provided & $\mathrm{SC}$ was initially invaded area. \\
\hline Infrastructure & Serviced & - & - & $\begin{array}{l}\text { FV infrastructure was serviced } \\
\text { by MVC. }\end{array}$ \\
\hline $\begin{array}{l}\text { House } \\
\text { Consolidation }\end{array}$ & $\mathrm{SH}$ & $\mathrm{SH}$ & $\mathrm{SH}$ & $\begin{array}{l}\text { Self-Help was successful with } \\
\text { the help of maestro de hobra in } \\
\text { communities. }\end{array}$ \\
\hline $\begin{array}{l}\text { Urban } \\
\text { Improvement }\end{array}$ & - & SM & SM & $\begin{array}{l}\text { Urban self-management is not } \\
\text { required in FV, because infra- } \\
\text { structures were serviced by MVC. }\end{array}$ \\
\hline \multicolumn{5}{|l|}{$\underline{\text { Impact }}$} \\
\hline $\begin{array}{l}\text { Housing } \\
\text { Standard }\end{array}$ & Good & Good & Good & $\begin{array}{l}\text { Built good quality house with } \\
\text { satisfaction, though construc- } \\
\text { tion took time for some families. }\end{array}$ \\
\hline $\begin{array}{l}\text { Community } \\
\text { Bonding }\end{array}$ & Mixed & Good & Good & $\begin{array}{l}\text { Good relationship among long } \\
\text { resided families but hesitation } \\
\text { can be seen with tenants and } \\
\text { new owners in FV. }\end{array}$ \\
\hline $\begin{array}{l}\text { Neighbourhood } \\
\text { Security }\end{array}$ & Poor & Good & Good & $\begin{array}{l}\text { Poor security in FV due to } \\
\text { inflow of migrants; despite } \\
\text { closing community gates during } \\
\text { night time and having well } \\
\text { serviced streetlights. }\end{array}$ \\
\hline \multicolumn{5}{|l|}{$\underline{\text { Side Effect }}$} \\
\hline $\begin{array}{l}\text { Willingness to } \\
\text { resettle in } \\
\text { other place }\end{array}$ & Likely & Unlikely & Unlikely & $\begin{array}{l}\text { Despite satisfaction with the } \\
\text { house, families in FV have } \\
\text { provision of re-settling instead } \\
\text { of improving their home, which } \\
\text { became stronger due to security } \\
\text { reasons. }\end{array}$ \\
\hline
\end{tabular}

SH: Self-help housing, SM: Urban self-management

\section{Acknowledgement}

This study was supported by Global Center of Excellence for Sustainable Urban Regeneration, the University of Tokyo. We appreciate the help received by Mr. Naotoshi Ichiki and Mr. Orlando with the local survey in Lima.
Note

*1) In Peru, informal settlements are given different names according to various periods: Barriadas, Pueblos Jovenes, Asentamiento Humano etc.

*2) The population of costa increased from approximately $3,860,000$ in 1961 to $6,240,000$ in 1972 and for sierra, from 5,180,000 to $5,950,000$. The area of Lima region has expanded 16 times larger from 5,000 [ha] in 1940 to 78,000 [ha] in $2000^{2)}$.

*3) The two levels of land-and-utilities are basic plots-supplied with pit latrines and communal water supply, and normal plots-supplied with individual water and sewer connections.

*4) The construction of the core house and occupation phase is usually referred to as the process of "consolidation".

*5) In Peru, Banco de Mateiral subsidized loans for construction materials for housing consolidation during 1970s. However, it was common that people could not afford to pay back the loan after two months and therefore, this policy was abandoned then after ${ }^{* 13)}$.

*6) PREVI (Proyecto Experimental de Vivienda) PP1 (Pilot Project 1) is Type IV / Method A housing project launched in 1969 and partly realized in 1972 by United Nations. This project failed for same reasons as seen in other aided self-help projects with high quality core house units, not affordable for the low-income population ${ }^{18)}$.

*7) Type IV sites and services project in San Martín de Porres was implemented by United Nation as part of PREVI PP3. However, the project site is currently one of the most dangerous areas in Lima and survey had to be terminated for security reasons.

*8) Servicio Aerofotogrrrofo Nacional in Lima (Copy Right)

*9) Interview with the community leader in FV.

*10)SC sites and services project was planned with full serviced infrastructure, 867 plots of 120 to $200 \mathrm{~m}^{2}$ and seven community facilities such as school and hospital ${ }^{19}$.

*11) Interview with the community leader in SC.

*12) Interview with Mr. Antonio Aragon, currently working in MVC who was responsible for VES at the time of implementation.

*13) Interview with Arq. Luis Pizarro, director of MVC.

*14)Interview with the community leader in VES.

*15) The year of occupation is not the same as project completion year. Some people prefer to live in other place until they have enough money to start construction. Project completion year for FV is $1977, \mathrm{SC}$ is 1981 and VES is 1971.

*16) The previous owner of house 3 had already completed the first floor and therefore the current owner was not involved in the consolidation period of the house.

*17) Small stoves, usually portable ones were used before the kitchen was constructed.

*18) Normally, tenants will only rent a room with no individual kitchen.

*19) Maestro is unlicensed architect / contractor living in the community.

*20) $1 \mathrm{~m}^{2} \fallingdotseq 25 \mathrm{US} \${ }^{* 13)}$

*21)Housing schemes planned in sites selected anew which usually requires relocation of low-income population such as sites and services schemes.

*22) "Community bonding" and "neighbourhood security" has been introduced in the evaluation because these two were the distinctive points mentioned during the interviews as factors of impact on the neighbourhood preference.

*23) FV has been constructed under organized management with government servicing infrastructure at the time of implementation, which is different from area-based community organizations such as in SC and VES.

*24)For example in Thai society, people prefer to have a very small complete house rather than a large incomplete house ${ }^{20)}$.

*25)Dandora sites and services in Nairobi, Kenya has been considered as failure for the evidence of subletting and selling ending up with only $20 \%$ original owners as of $1987^{9}$. However, from survey held in 2012 by the author interviewing 34 residents, it was found that similar method to urban self-management has been accomplished to improve the area in terms of providing services and security. 


\section{References}

1) P. McAuslan: Urban Land and Shelter for the Poor, Intl Inst. for Environment, 1985

2) INEI Censos Nacionales de Población y Vivienda, 1940, 1961, 1972, 1981, 1993 y 2007.

3) C. Fukui: Urbanization and Problems Related to Poverty in Peru-A Study of the Current Situation in the Lima Metropolitan Area and Measures Aiming at its Enhancement-" Regional Policy Research 2(1-2), pp.57-73, 1999

4) F. M.Monzon and J. C. Oliden: Tecnologia y Vivienda Popular, Tecnologia Intermedia, Peru, 1990

5) W. Mangin: Latin American Squatter Settlements: A Problem and a Solution, Latin American Research Review, Vol. 2, No. 3 pp.65-98, 1967

6) J. F. C. Turner: Issues in Self-help and Self-managed Housing, In Ward, P. M. Self-help Housing: A Critique, Mansell Publishing, London, pp.99-113, 1982

7) R. J. Skinner and M. J. Rodell (eds): People, Poverty and Shelter: Problems of Self-help Housing in the Third World, London, Methuen, 1983

8) A. A. Laquian: Sites, Services and Shelter-an Evaluation, HABITAT INTL., Vol. 7, No. 516, pp.21l-215, 1983

9) UNCHS: Case Study of Sites and Services Schemes in Kenya" UN-Habitat, 1987

10) K. Harada: Parque industrial in Villa El Salvador, Peru and its micro-industrialization, Annals of economic research No.20, pp.105-108, 2002

11) I. Imparato and J. Ruster: Slum Upgrading and ParticipationLessons from Latin America, The International Bank for Reconstruction and Development, The World Bank, 2003

12) H. Kajihara and T. Kidokoro: The Impact of Land Tenure Systems on Informal Urban Development in African Cities-A Case Study of Nairobi, Lusaka and Dakar-, Papers on city planning. City planning review (48), 2013

13) M. Bamberger, B. Sanyal and N. Valverde: Evaluation of Sites and Services Projects, The Experience from Lusaka, Zambia, World Bank Staff Working Papers, No. 548, 1982

14) J. Tamura: Re-Evaluation of Sites and Services Projects in Lusaka, Zambia, Summaries of Technical Papers of Annual Convention, Architectural Institute of Japan, Vol. 2013-07-31, pp341-342, 2013

15) T. Otsuki: Invisible Slums in Future Tokyo (Future Slum-in Prospect for Urbanization), Journal of architecture and building science / Architectural Institute of Japan Vol. 126 (1612), pp.38-41, 2011

16) R. B. Potter and S. Lloyd-Evans: The City in the Developing World, Longman, pp.137-158, 1998

17) T. Umehara: The transfiguration of Barriadas (an illegal district) in Lima" International Buddhist University bulletin No.45, pp.79-99, 2007

18) Supersudaca and J. Tamura: AND PREVI?, 10+1 No.47, INAX Publisher, pp.109-120, 2007

19) World Bank: Appraisal of the Urban Sites and Services Development Project Peru (Report No.1065a-PE), 1976

20) J. Tamura and N. Shima: Research on Informal Housing Supply Mechanism in Sites and Services Area: The Case of Bangkok, Reports of the City Planning Institute of Japan, No. 10, pp.213-216, 2012

\section{和文要約}

リマ都市圏における低所得者層の居住環境改善プロセスの実態と課

セルフ・ヘルプ・ハウジングとアーバン・セルフ ・ マネージメント に着目して

都市部の急速な人口増加に伴って，ペルーでは 70 年代より居住 環境改善策が重要な政策課題として実施されている。本研究ではそ の中でもペルーを起源とし，居住環境改善プロセスとして多くの政 策で実施されたにも関わらず，必ずしも地域住民へ順応されなかっ たセルフ・ヘルプの手法と, セルフ・マネージメントの仕組みに焦 点をあてる．分析方法としてはまず，アーバンプロセスと住居生成 プロセスを示すフロー図によって住居改善プロセスを分類し，異な る居住環境改善策の差異を示す。そして，リマ市内でこの分類が異 なる 3 つの地域を対象に，実地調査を通して約 40 年経過した今日 の居住実態を自主性の観点から分析することを目的とする.

（2013年 5 月10日原稿受理，2013年11月 6 日採用決定） 